\title{
The Institutionalization of Community Mediation for Resolving Merarik Marriage Disputes in Sasak Community
}

\author{
Hilman Syahrial Haq, Khudzaifah Dimyati, Absori, Nasri \\ Faculty of Law, Universitas Muhammadiyah Mataram, Indonesia. E-mail:hilmansyahrialhaq@gmail.com \\ Faculty of Law, Universitas Muhammadiyah Surakarta, Indonesia. E-mail: kd255@ums.ac.id \\ Faculty of Law, Universitas Muhammadiyah Surakarta, Indonesia.E-mail: absorisaroni_@gmail.com \\ Faculty of Law, Universitas Muhammadiyah Mataram, Indonesia. E-mail: mnasritamrin@gmail.com
}

\section{ARTICLE INFO}

\section{Keywords:}

Community Mediation, Conflict, Merarik

Marriage.

How to cite:

Haq, H.S., Dimyati, K., Absori, Nasri. The Institutionalization of Community Mediation for Resolving Merarik Marriage Dispute in Sasak Community. MEDIA HUKUM, +62274 387656 (Ext. 220)

\section{Article History}

Received: 29/12/2018

Reviewed: 18/01/2019

Revised:

Accepted: 24/06/2019

\begin{abstract}
Mediation is applicable for various disputes within the society, including family dispute. Such a method is commonly referred to as community mediation. This paper discusses the application of community mediation for resolving merarik marriage dispute in Sasak Community, Lombok. This socio-legal research conducted through both library-based study and field work. Interview and nonparticipatory observation have been conducted in several locations including Sesait Village, Mambalan Village and Rambitan Village. It is found that community mediation should be institutionalized in order to improve its effectiveness. The institutionalization of community mediation can be made by integrating it into the national justice system. It is expected that community mediation can be an alternative mechanism to the court system especially in handling merarik marriage disputes.
\end{abstract}

DOI: $10.18196 / j m h .20190118$

Copyright (C) 2019 MEDIA HUKUM. All rights reserved.

\section{Introduction}

The diverse nature of the Indonesian society warrant the different Adat Laws in use in the nation. And the use of these laws is not only at the level of principles and norms 
but also in resolving disputes within the society. ${ }^{1}$ The Indonesian population had traditional institutions, in the past, functioning as mediators within the community in which community heads acted as adat judges. ${ }^{2}$ For example, in Tapanuli of Karo Batak community, there is a village consultation organization known as runggun adat which helps in handling and resolving disputes in that community. Also, in Aceh, there is various local wisdom concerning how disputes are resolved in the community, such as di'iet, sayam, suloh, peumat jaroe. Bali, as well, has a peacekeeping body known as muditha kertas sabha or kertha dese, meaning a place for seeking peace, krame dese. There are also customary institutions in Maluku, especially the central part, known as saniri negeri and saniri raja putih. ${ }^{3}$ These institutions help in dispute resolution.

There are also dispute resolution bodies in other regions like Sasak, Samawa, and Mbojo. For example, people living in Samawa on Sumbawa Island have customary institutions known as adat tana samawa or tokal adat, the community of Mbojo has mbolora dampa and kesama nggahi ra eli, while Sasak people who live in the island of Lombok have soloh or begundem, for settling any dispute outside the court. These show there is a long history of establishing traditional dispute resolution institutions. ${ }^{4}$ However, the existence of community mediation has been marginalized in recent times. This is because most people now see courts of law as the best place to resolve disputes, which has given rise to buildup of cases in these courts.

Also in the Sasak community, merarik is the most common form of marriage. And looking at the modus operandi of this form of marriage, it contradicts the provision of the law, especially the Article 332 Paragraph (1) to 1 of the Criminal Code which prohibits an individual from taking away an immature female for marriage without the parents or guardians consent, even if such a girl agrees to the marriage. What happens in merarik is that the girl escapes from the parents leading to some unlawful acts towards the girl from those who want the marriage, like kidnapping, sexual intercourse, and the likes. The reasons this form of marriage gained ground were not known even though Islam, which the major religion of the people in that region, goes against it, but then, it could be as a result of the long traditional history.

Moving away from these traditional norms, the implementation of Adat Law needs to be balanced by employing formal means of resolving issues such that its existence is not marginalized by decisions from courts of law. And that things should be in place at the beginning to strengthen the position of Adat Law when compared to the formal national legal system since it sometimes negates some of the decisions of Adat Law which should be a reference point for developing the national law.

Therefore, the purpose of this study is to examine the following research questions; how is the description of the conflict in merarik marriage attractive in the Lombok Sasak community and how are efforts to institutionalize community mediation as an alternative to settling marital merarik marriage dispute in Lombok's Sasak community?

${ }^{1}$ Haq, H.S. and Nasri. (2016). “Mengukuhkan Eksistensi Hukum Adat dalam Sistem Hukum Indonesia: Studi terhadap Bale Sangkep Desa Sebagai Mediasi Komunitas di Desa Sintung Lombok Tengah Nusa Tenggara Barat". Prosiding Konferensi Nasional Ke-4 Asosiasi Program Pascasarjana Perguruan Tinggi Muhammadiyah (APPTM): 251-256.

2 Farikhah, M. (2018). "Konsep Judicial Pardon (Pemaafan Hakim) dalam Masyarakat Indonesia”. Jurnal Media Hukum, 25(1): 81-92.

${ }^{3}$ Haq, H.S. and Hery Sumanto. (2016). "Mengukuhkan Eksistensi Hukum Adat dalam Sistem Hukum Indonesia: Studi terhadap Pelembagaan Mediasi Komunitas". Jurnal Yustisia Merdeka, 2(2): 15-26.

4 Ibid., p. 22. 


\section{Method}

This is socio-legal or non-doctrinal research in which the law is view as a major standard among the social actors, as seen in the interactions between them. ${ }^{5}$ Therefore, this is descriptive research since it aims to describe the conflicts in marriages as well as efforts to institutionalize community mediation as a means of conflict resolution. It was conducted in Sesait Village, North Lombok Regency, Mambalan Village, West Lombok Regency and Rambitan Village, all within the Central Lombok Regency. The selection of these locations was based on the fact that people in these areas still keep the values of some local wisdom like the tradition of merarik marriage and the continuity of traditional institutions that function as mediators within the community.

The research lasted for a period of six months, starting from January to May 2017. The data was collected by granting interviews to informants as well some observant that did not participate in the research, who just considered the problems. Some library materials related to the study were also consulted. Then, the data obtained are analyzed qualitatively to describe the variables relating to the problem under consideration.

\section{Analysis and Results}

\subsection{Description of Conflict in Merarik Marriage in Lombok's Sasak Community}

Marriage is the coming together of a man and a woman to form a bond as husband and wife, to form a happy family. It is a process in which human movement from the level of adolescents to family life. Therefore, marriage is considered as the first and foremost foundation in forming a community. And the people of Sasak people also have other forms of marriage like memagah, belakoq, surrendering the law, married hanging, and the likes, but merarik is the most common form of marriage in Sasak society. Therefore, when it comes to marriage, merarik is assumed to be the highest form of local wisdom exclusively for the people of Sasak. ${ }^{6}$ It involves freeing a girl from the bond of the parents and family and she has to run away without the parents' consent in that process. $^{7}$

It is also worth noting that merarik has its uniqueness when compared with other forms of marriage in society. Historically, people are placed within three social strata in Sasak. And the adat law prohibits women in the first group, which is the noble class, from getting married to those in second and third groups since they belong to a lower social class. However, the law allows these two classes to intermarry. Therefore, this form of marriage was a result of protests from these two groups-second and third, against the noble class, as a way of maintaining their self-esteem. ${ }^{8}$ And according to Kurdap, the head chief of Sade Desa Rambitan hamlet, "Merarik is a symbol of honor and prestige for the parties who are involved in it since the indigenous people

\footnotetext{
5 Wignjosoebroto, S. (2002). Hukum: Paradigma, Metode dan Dinamika Masalahnya. Jakarta: Elsam HuMa, p. 148.

6 Tahir, M. (2008). “Tuan Guru dan Dinamika Hukum Islam Di Pulau Lombok”. Jurnal Asy-Syir'Ah, 42(1): 85-115.

7 The results of an interview with Raden Rais, as a community leader in Mambalan village, January 12, 2017.

8 Rahman, F. (2013). Pernikahan di Nusa Tenggara Barat antara Islam dan Tradisi. Mataram: LEPPIM IAIN Mataram, p. 135.
} 
assumed that their daughters were valuable and could only exchange them for such value."9 Also, this "pulling" or "running away" is important in Sasak marriages because most girls consider men that could dare to run away with them as strong fellow since the parents would never approve such marriages. ${ }^{10}$

And putting it in the right context, Sasak people are generally permissive to merarik practices for five reasons, these include: (1) it is seen a custom which is not entirely contrary to Islamic teachings; (2) the idea is an ancestral heritage that has become a tradition; (3) its attractiveness can increase the happiness of a married couple; (4) it can improve the social status of either of the couples; (5) it is considered as something normal. ${ }^{11}$

Merarik can also be seen as a customary way of making Sasak women independent in choosing their life partners which help in minimizing offenses that could arise as a result of the girl rejecting the marriage proposal as normally experienced with belakoq marriage. ${ }^{12}$ And in practice, merarik is not always going well because it always involves underage women, it also involve people in different social classes which is always disapproved by the girl's parents, as well as the challenges always encounter in determining the right payment for ajikrame or pisuke, which is the elopement gift by the man to the girl's family. Therefore, the outcome of conflict from this tradition could be latent or manifest conflict.

Latent conflict occurs when a group is not satisfied with any of the marriage conditions or penalties but not showing it outwardly. ${ }^{13}$ The manifest conflict, on the other hand, could end in court. There was a particular case in Aik Darek, Central Lombok in 2008, which occurred because the woman's parents disapproved the marriage after the daughter was being taken away by her lover, even though it was done with her request. Based on Article 332 paragraph (1) to 1 of the Criminal Code, the Praya District Court, who handled the court case with number 232/Pid.B/2008/PN.Pra sentenced the man to one month and fifteen days imprisonment. ${ }^{14}$

Considering some of these disputes with this practice, there is a need for full participation and mediation within the community, to maintain its nobleness. And the authorities for mediation purposes should be within the community for resolving disputes, except in criminal cases like a conflict in the Kelantih area of Central Lombok in 2010, where one person was killed, three people seriously injured and three houses burnt as a result of the misunderstandings in handling the case.

\subsection{Institutionalization of Community Mediation as an Alternative to Settling Attractive Marriage Merarik Disputes in the Lombok Sasak Community}

The resolution of disputes based on local wisdom, as in the case of merarik, is seen as a way of reviving and maintaining cultural values which could go into extinction as a result of the current modernization in the society at large. And as a nation that is rich

\footnotetext{
${ }^{9}$ Interview on February 8, 2017.

10 Bertholomey, J.R,. (2001). Alif Lam Mim; Kearifan Masyarakat Sasak. Yogyakarta: Tiara Wacana, p. 204.

11 Yasin, N. (2008). Hukum Perkawinan Sasak. Malang: UIN Malang Press, p. 169.

12 The results of an interview with Raden Rais, as a community leader in Mambalan village, January 12, 2017.

13 Sipayung, M.E,. (2016). “Konflik Sosial dalam Novel Maryam Karya Okky Madasari: Kajian Sosiologi Sastra". Jurnal Ilmiah Kebudayaan Sintesis, 10 (1): 22-34.

14 Putro, W.D., (2013). "Perselisihan Sosiological Jurisprudence dengan Mazhab Sejarah dalam Kasus Merarik". Jurnal Yudisial, 6 (1): 48-63.
} 
in customs, the state should provide space and facilities in the community to support the values from this local wisdom, as well as in resolving disputes.

According to Ade Saptomo, the family is an institution, within the social life, used to resolve disputes and in reaching consensus, which is part of the rich cultures of the Indonesians, but is not naturally formed to resolve disputes since the judiciary is saddled with that responsibility. ${ }^{15}$ Also, the national judicial system has some weaknesses, for example, when a judge lacks in-depth knowledge of the social conditions of the warring parties, the judge could neglect these social aspects while deciding the case. The judicial system majors on the quantity and speed of cases handled, rather than the quality of the decisions taken on those matters. And according to Bernard, judges could minimize the discrepancy between the law and the justice given in various cases by understanding the legal values of the society. ${ }^{16}$

In the past, Sasak people regarded berugak or santren (mushola) as the best place to resolve all form of disputes, including marital ones, with village officials, religious leaders and community leaders acting as mediators. There was nothing formal there, and the parties felt comfortable in expressing their problems openly. This makes the dispute resolution easier compared with making it formal by going to the police station or a court of law because of the cost implications. But now, the community is beginning to see the court as the best place to resolve disputes since court decisions always come with the legal bond. ${ }^{17}$

The following are the principles identified as the basis for resolving disputes in the Sasak community:

a. The Principle of Godhead and Self-control (betegel leq reden neneq), which allows disputes reconciliation through the commands of Allah SWT and whatever decision is taken during this period, must be voluntarily adhered to by the warring parties.

b. The Principle of Equality of Rights and Togetherness of rights (doe sopoq, bareng ngepe), which settles disputes based on equality without any discrimination in terms of gender, social status, or age. Everyone is with equal right and must be treated fairly.

c. The Principle of Harmony and Family (awaq sopoq, saling peririq, saling angkat, saling ajinin, saling sedok), which makes having family spirit a priority in settling a dispute among family members.

d. The Deliberation and Consensus Principle (soloh), involves dispute resolution on the deliberation and consensus reached based on the local wisdom values.

e. The Principle of Justice (endeq naraq bine kire, tarik nyacap), which resolves disputes based on peaceful decisions that include the rights of both warring parties.

In institutionalizing mediator bodies in the community, it is necessary to look at the way it is being done in more civilized world like Australia, where the process is ultimately based on government policy such that all civil disputes are resolved through

\footnotetext{
15Saptomo, A. (2001). Hukum dan Kearifan Lokal: Revitalisasi Hukum Adat Nusantara. Jakarta: PT Gramedia Widiasarana Indonesia, p. 97.

16Tanya, B.L,. (2006). Hukum, Politik dan KKN. Surabaya: Srikandi, p. 13.

17 The results of interviews with Abidin Tuarita as a community leader in the village of Sesait, February 11, 2017.
} 
mediation, as stated the Chief Executive/Registrar of the Federal Court of Australia, Warwick Soden, at an international seminar with the theme "Institutional Development to Support Community Mediation through the Role of Government, Courts and NonGovernmental Organizations", organized by Australia Indonesia Partnership for Justice (AIPJ) in collaboration with the Indonesian Supreme Court, implemented in 2015 in Mataram.

Even though Australia adopted the British legal system, known as Anglo-American legal system or Anglo-Saxon, the government still recognize a traditional justice institution in resolving disputes because they consider the judiciary as necessarily not the best in resolving disputes. This is because the legal problems common within the community are always caused by social issues. Therefore, this led to the formation of Community Justice Centers in the 1980s with the sole aim of handling trials outside the court.

Initially, the issues normally resolved through these Community Justice Centers were those revolving around families, but after its development to the status of "court outside the court," it started handling many commercial cases. And this helps to reduce the backlog of cases in the court of law. The success of Community Justice Centers as an alternative dispute resolution centers, as well as in solving legal matters, was considered as very important in the administration of law in Australia. Hence, CourtAnnexed Mediation was formed in 1983.

Then, the Federal Court Mediation Program was formed in 1987, with a pilot program in the NSW Registry that had the authority to mediate disputes based on the value of the case. The parties first determine if the case can be resolved through mediation or not before handling it. And in the early 1990s, mediation received encouragement and credibility from the community; this later became a movement, for example, several courts made a list of mediators, which later became a reference for conducting mediation regularly as well as a reference for parties to choose these mediators. In June 1991, the Federal Court of Australia 1976 Act was amended to allow courts to resolve disputes through mediation, provided the warring parties agreed to it.

More so, the Federal Attorney General announced the formation of the National Alternative Dispute Resolution Advisory Council (NADRAC) in 1995, to encourage the expansion of alternative dispute resolution centers, and also as a strategy to reduce legal costs and improve access to justice. It is seen as a solution to court insensitivity, high legal charges as well as the slow pace of court cases. Put in the right perspective, NADRAC helps in achieving and maintaining a quality, accessible, and integrated federal alternative dispute resolution system through regulated guidelines. The government thereby issues a legal regulation on the need to resolve civil matters through mediation in 2012. Hence, it developed rapidly in Australia.

There is a mediation forum like those described in Australia in Indonesia. According to the study by Keebet von Benda Beckman in the Minangkabau countryside, West Sumatra, there are means for disputing parties to make choices among existing institutions like customary institutions or district courts, in resolving disputes. ${ }^{18}$ And based on the findings of Bernard in Sabu Community, resolving disputes on vital matters like land disputes, disputing parties always seek the judgment of leaders who are knowledgeable about the disputed land. And leaders with a rich history of the

18 Bernard, L. Tanya. (2011). Hukum dalam Ruang Sosial. Yogyakarta: Genta Publishing, p. 24. 
community involving customs, traditions, religious, and social matters act as the head of the various forum where issues could be resolved through mediation. And to some extent, it has the potential of giving the right judgment because the state law might have very little or no knowledge about the disputed land, which could result in "historical error." This is in line with Trubek's thesis which states that several disputes are not suitable for resolution at courts, namely family disputes, controversies between neighbors, matters involving a small amount of money, and problems from managing long-term trade relations. ${ }^{19}$

The various discussions on the need to strengthen community mediation in recent times have led to two major concepts on how it should be positioned about the already established state judicial system. The first option is to integrate the mediation institutions into the state justice system. This proposal aims to provide a stronger binding force for the results of mediation that was born through a community mediation forum. The second option is the substantial strengthening of community mediation without the need for institutional integration as the first choice. The goal of the second option is to reduce the burden of cases accumulating in the court since there are options in settling disputes. 20

The Supreme Court of the Republic of Indonesia, in a bid to encourage dispute resolution through mediation, issued the Supreme Court Decree Number 1 of 2008 on procedures for mediation in courts (PERMA No. 1 of 2008). Article 23 of this PERMA provides an opportunity for disputing parties to settle their disputes outside the court provided that they are assisted by a certified mediator. And in situations where one or both parties is without a certified mediator, the Supreme Court made amendment in this regards with Article 36 of the law which states that "Parties with or without the assistance of a certified Mediator who have succeeded in resolving the disputes outside the Court with a Peace Agreement can submit the Peace Agreement in a Court that is authorized to obtain a Peace Deed."

This development later revived the roles of community and traditional leaders in customary institutions (Krame Dese) formerly known as Village Peace Judges (Dorp Sacten) whose existence was annulled by the Emergency Law No. 1 of 1951 and the power of the court of justice, self-reliance and customary justice were transferred to the state court. Consequently, a new chapter for the institutionalization process of community mediation in NTB was opened in 2015 through a collaborative effort between the Supreme Court of Indonesia and AIPJ to resolve disputes through court mediation. The project was established in three provinces - West Sumatra, NTB and Banten. Among these provinces, only NTB responded well, and through the West Nusa Tenggara Governor Regulation No. 38 of 2015 concerning Bale Mediation, there is need to revive the values of the local wisdom of the NTB community especially in resolving disputes.

In that regulation, there are some considerations. First, the resolution of conflict based on the local wisdom in the form of consensus and agreement. This is as the part of

${ }^{19}$ Ibid

${ }^{20}$ Arizona, Y. "Kedudukan Peradilan Adat dalam Sistem Hukum Nasional" on Tody Sasmitha Jiwa and Sandra Dini Febri Aristya. (2015). “Kajian tentang Relevansi Peradilan Adat terhadap Sistem Peradilan Perdata Indonesia".Jurnal Mimbar Hukum, 27 (1): 57-67. 
behavior that lives and develops in the society of West Nusa Tenggara. It also will guarantee the harmony life in society. Second, the resolution of conflict based on the local wisdom in the form of mediation and it is one of the alternative ways to solve the conflicts outside of the court.

Critically looking into the task of Bale Mediation, some shortcomings were found which have affected them in the given tasks and responsibilities to conduct mediation But in practice, many people expect the Bale Mediation to mediate the disputes they face. And with this, there was an encouragement from the community to improve the status of the Governor's Regulation into a Regional Regulation. This resulted in the Regional Regulation No. 9 of 2018 about the Bale Mediation, which is a unique local regulation because it is full of legal breakthroughs. Previous laws and regulations in Indonesia generally allow only the mediation of civil cases, however, the Local Regulation No. 9 of 2018 (PERDA No. 9 Th. 2018) went one step ahead in terms of breakthroughs by also resolving criminal cases from minor crimes and marital crimes.

Therefore, the existence of the Regional Regulation is expected to be a means for Sasak people to strengthen the existence of marriages through consensus that is in favor of the interests of the generality. And to strengthen the position of the institution, it is necessary to develop a network of Bale Mediation at the village level by effectively using some community mediation bodies such as the Village Security Agency Sintung, Sempage Valley Village Council, Fair Body Pujut Village, Krame Village Mataram and the likes, for settling unresolved marital disputes at the village level.

\section{Conclusion}

Based on these findings, the authors conclude as follows: Marriage in Sasak society has the potential to produce either latent or manifest conflict. The latent conflict could be as a result of resignation on the part of parents whose daughters were taken away (merarik), while the manifest conflicts occurred when reports were made and as a result becomes a court matter. Institutionalization of community mediation is done by integrating it into the national justice system to strengthen the results and make it in the form of a legal court decision. This was reinforced by the establishment of NTB Regulation No. 9 of 2018, in which Bale Mediation is seen as a legal umbrella for the Sasak people in the event of resolving marital disputes. The government needs to consider the values of local wisdom in the respective communities as a guide in improving national law and also renew criminal law so that there is no clash of values that can harm the interests of indigenous peoples in the future.

The efforts to institutionalize community mediation as an alternative to settling marital marriage merarik dispute in Lombok's Sasak community resolved through the court, have the potential to weaken the existence of local laws. Therefore, Bale Mediation needs to be strengthened through networks at the village level by effectively using various mediation bodies within the community. 
References

Books:

Bertholomey, J.R. (2001). Alif Lam Mim; Kearifan Masyarakat Sasak. Yogyakarta: Tiara Wacana.

Mushadi. (2007). Mediasi dan Resolusi Konflik di Indonesia. Semarang: Walisongo Mediasi Center.

Rahman, F. (2013). Pernikahan di Nusa Tenggara Barat antara Islam dan Tradisi. Mataram: LEPPIM IAIN Mataram.

Saptomo. A. (2001). Hukum dan Kearifan Lokal: Revitalisasi Hukum Adat Nusantara. Jakarta: PT Gramedia Widiasarana Indonesia.

Tanya, B.L. (2006). Hukum, Politik dan KKN. Surabaya: Srikandi. . (2011). Hukum dalam Ruang Sosial. Yogyakarta: Genta Publishing.

Tim Departemen Pendidikan dan Kebudayaan. (1995). Adat dan Upacara Perkawinan Daerah Nusa Tenggara Barat. Jakarta: Depdikbud.

Wignjosoebroto, S. (2002). Hukum: Paradigma, Metode dan Dinamika Masalahnya, Jakarta: Elsam HuMa.

Yasin, N. (2008.) Hukum Perkawinan Sasak. Malang: UIN Malang Press.

\section{Journal Articles:}

Farikhah, M. (2018). "Konsep Judicial Pardon (Pemaafan Hakim) dalam Masyarakat Indonesia". Jurnal Media Hukum, 25 (1), 81-92. doi: 10.18196/jmh.2018.0104.81-92.

Haq, H.S. \& Sumanto, H. (2016). “Mengukuhkan Eksistensi Hukum Adat dalam Sistem Hukum Indonesia: Studi terhadap Pelembagaan Mediasi Komunitas". Jurnal Yustisia Merdeka, 2 (2).

. \& Hamdi. (2016). "Perkawinan Adat Merarik dan Tradisi Selabar di Masyarakat Suku Sasak". Jurnal Perspektif, XXI (3).

Jiwa, T.S., \& Aristya, SDF. (2015). “Kajian Tentang Relevansi Peradilan Adat terhadap Sistem Peradilan Perdata Indonesia". Jurnal Mimbar Hukum, 27 (1).

Putro, W.D. (2013). “Perselisihan Sosiological Jurisprudence dengan Mazhab Sejarah dalam Kasus Merarik". Jurnal Yudisial, 6 (1).

Sipayung, M.E. (2016). “Konflik Sosial dalam Novel Maryam Karya Okky Madasari: Kajian Sosiologi Sastra". Jurnal Ilmiah Kebudayaan Sintesis, 10 (1).

Tahir, M. (2008). “Tuan Guru dan Dinamika Hukum Islam di Pulau Lombok”. Jurnal Asy-Syir'Ah, 42(1).

\section{Proceeding:}

Haq, H.S. dan Nasri. (2016). “Mengukuhkan Eksistensi Hukum Adat dalam Sistem Hukum Indonesia: Studi terhadap Bale Sangkep Desa sebagai Mediasi 
Komunitas di Desa Sintung Lombok Tengah Nusa Tenggara Barat". Prosiding Konfrensi Nasional Ke-4 Asosiasi Program Pascasarjana Perguruan Tinggi Muhammadiyah (APPTM), 251-256. 